\title{
Improving dialogue among researchers, local and indigenous peoples and decision-makers to address issues of climate change in the North
}

\author{
Terry V. Callaghan, Olga Kulikova, Lidia Rakhmanova, \\ EImer Topp-Jørgensen, Niklas Labba, Lars-Anders Kuhmanen, \\ Sergey Kirpotin, Olga Shaduyko, Henry Burgess, Arja Rautio, \\ Ruth S. Hindshaw, Leonid L. Golubyatnikov, Gareth J. Marshall, \\ Andrey Lobanov, Andrey Soromotin, Alexander Sokolov, \\ Natalia Sokolova, Praskovia Filant, Margareta Johansson
}

Received: 16 May 2019/Revised: 20 August 2019/Accepted: 4 October 2019/Published online: 12 November 2019

\begin{abstract}
The Circumpolar North has been changing rapidly within the last decades, and the socioeconomic systems of the Eurasian Arctic and Siberia in particular have displayed the most dramatic changes. Here, anthropogenic drivers of environmental change such as migration and industrialization are added to climateinduced changes in the natural environment such as permafrost thawing and increased frequency of extreme events. Understanding and adapting to both types of changes are important to local and indigenous peoples in the Arctic and for the wider global community due to transboundary connectivity. As local and indigenous peoples, decision-makers and scientists perceive changes and impacts differently and often fail to communicate efficiently to respond to changes adequately, we convened a meeting of the three groups in Salekhard in 2017. The outcomes of the meeting include perceptions of how the three groups each perceive the main issues affecting health and well-being and recommendations for working together better.
\end{abstract}

Keywords Dialogue - Environmental change · Indigenous peoples · Policy-makers · Researchers . Siberia

\section{INTRODUCTION}

The Circumpolar North has been changing rapidly within the last decades, and the socioeconomic systems of the

Electronic supplementary material The online version of this article (doi:https://doi.org/10.1007/s13280-019-01277-9) contains supplementary material, which is available to authorized users.
Eurasian Arctic and Siberia in particular have displayed the most dramatic changes (Forbes et al. 2009; Kumpula et al. 2012). In this region, anthropogenic drivers of environmental change such as migration, industrialization and urbanization (Orttung and Reisser 2014) are added to climate-induced changes in the natural environment, for example warming of the atmosphere, reduced area of sea ice, permafrost thawing and increased frequency of extreme events (AMAP 2017a). Understanding and adapting to both types of changes are important to both the local peoples in the Circumpolar North (Anisimov and Orttung 2018) and the wider global community as changes to climate conditions in one part of the Earth have knockon effects for other regions (e.g. Francis and Vavrus 2012). Coping with threats and gaining benefits from the evolving changes are both possible responses but choices should be informed by the best available knowledge. Global warming has been most pronounced in the Arctic during the last decades (Overland et al. 2017). The largest landmass in the region, Siberia (total area 13 million $\mathrm{km}^{2}$; Fig. 1), is, however, relatively little studied. Because of the vast size of Siberia, its impacts on its local populations and its potential feedbacks to global climate, it should be a priority for research. Nevertheless, Siberia should not be studied in isolation: it is part of the Earth System and several environmental and socioeconomic processes share analogues in other Arctic regions, e.g. permafrost thaw, migration and traditional life style changes. Studies which compare processes and responses between Arctic regions are therefore crucial in order to expedite dissemination of knowledge and coping strategies.

Attempts to cap the global temperature increase by mitigation of $\mathrm{CO}_{2}$ emissions have so far failed. Compared to the initial caps set in the Paris Agreement (Horowitz 2016), of 


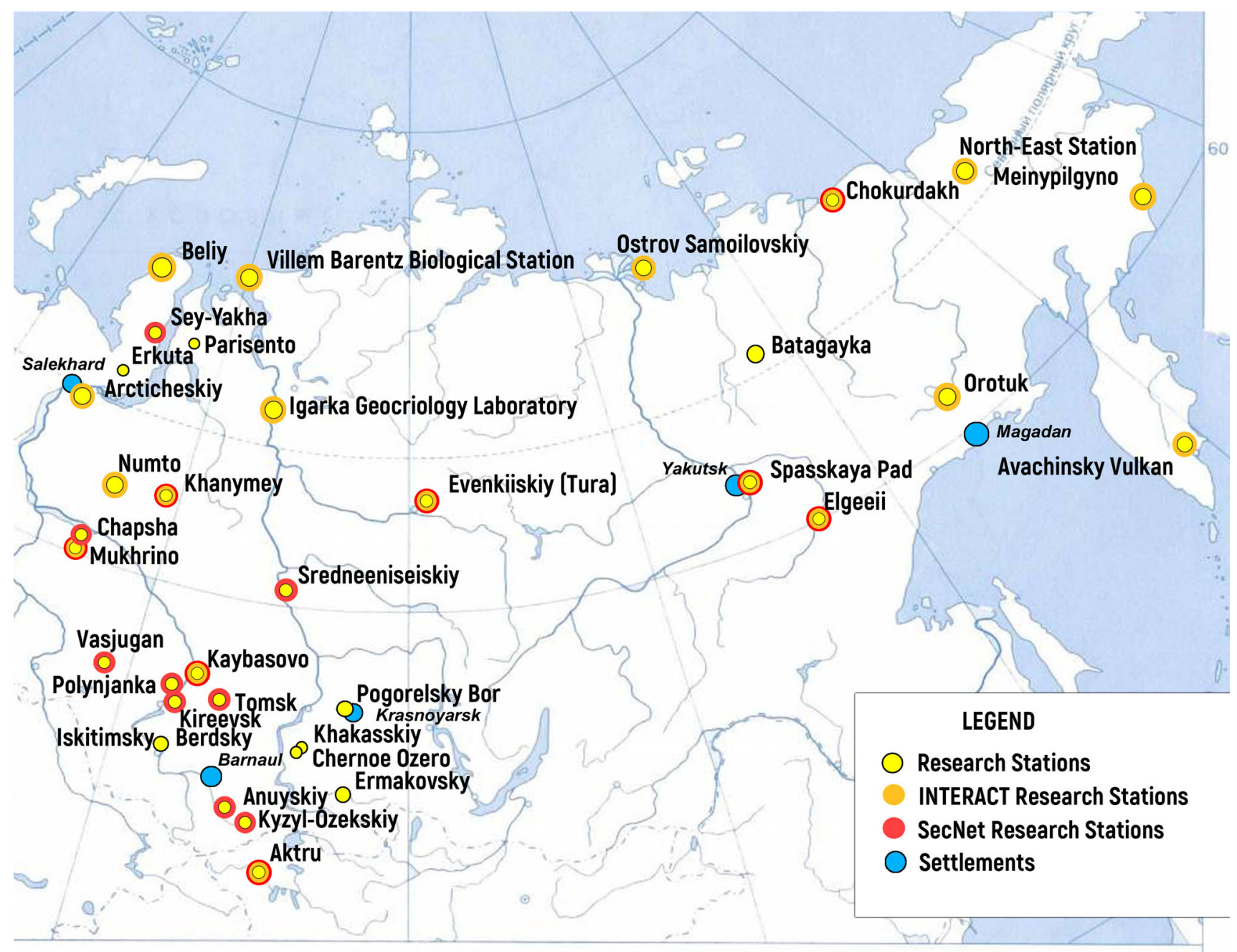

Fig. 1 Research stations in Siberia

$1{ }^{\circ} \mathrm{C}$, and then below $2{ }^{\circ} \mathrm{C}$ globally, compared to pre-industrial levels, the mean annual surface temperature in the north of Siberia has increased markedly by about $4{ }^{\circ} \mathrm{C}$ over the past 50 years (Fig. 2). Also, the frequency and intensity of weather extremes (both rainfall and temperature) have increased with an associated increase in the frequency of large and severe wildfires and dust storms which have impacts that often extend far beyond Siberia and Northern Eurasia, affecting even global markets and raising concerns about global food security (Groisman et al. 2017).

Therefore, the need to adapt to a future, warmer climate in Siberia is urgent. Simplistically, adaptation requires (i) identification of the problem by researchers and local peoples, (ii) planned responses by researchers, local peoples and decision-makers, (iii) implementation of planned responses by decision-makers and local peoples and (iv) monitoring of the effects of adaptation and mitigation strategies by researchers and local peoples. This scheme requires that researchers, local peoples and decision-makers work together better than at present. To achieve this goal and to provoke thoughtful dialogues, an international meeting was held to bring together representatives of local and indigenous peoples, researchers and decision-makers, with a focus on issues related to climate change impacts in the Arctic.

The methodology behind this study is to summarize the results of the 2nd Siberian Environmental Change Network (SecNet: http://www.secnet.online/home-eng.html) workshop "Winter Weather and Climate Extremes: how can researchers, authorities and local peoples work together to record, predict and adapt?" held in Salekhard, Russia on 1-3rd November 2017. The workshop was co-organized by INTERACT (https://eu-interact.org/). The workshop's methodology was to bring representatives of the three groups (researchers, local peoples and decision-makers) together. The main objective of this study was to explore how to improve communications, make research more relevant to local needs and facilitate adaptation actions. The 


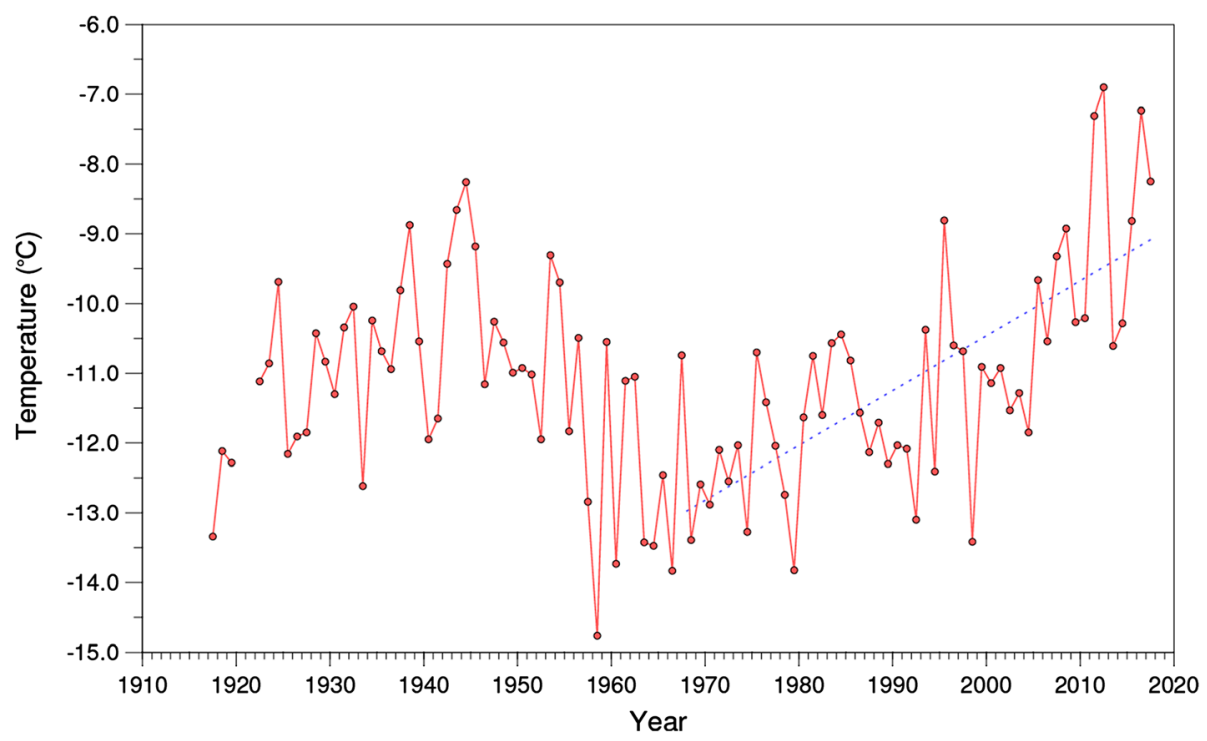

Fig. 2 Mean annual temperature record from Ostrov Dickson station $\left(73.5^{\circ} \mathrm{N}, 80.3^{\circ} \mathrm{E}\right)$. The dashed line shows the $\sim 4{ }^{\circ} \mathrm{C}$ warming in the past 50 years (1968-2017). Data were acquired from the Russian Research Institute of Hydrometeorological Information World Data Centre (RIHMIWDC) (http://aisori.meteo.ru/ClimateE) with some missing values infilled from the Koninkklijk Nederlands Meteorologisch Institute (KNMI) Climate Explorer data portal (https://climexp.knmi.nl) and the Berkeley Earth dataset (http://berkelyearthlbl.gov/stations/169952)

methodology and format of the meeting gave the participants an opportunity to discuss issues of concern to them in groups and to present the main outcomes of the discussion in plenum to identify possible solutions for future collaboration. In this study, we present issues perceived as important by each group and present jointly agreed recommendations.

\section{ISSUES PERCEIVED BY RESEARCHERS}

\section{The main issues affecting the Siberian environment and ecosystems}

Increasing temperatures and changes in precipitation patterns which impact the wider Siberian environment (AMAP $2017 \mathrm{a}, \mathrm{b})$ are caused by an increase in global carbon emissions (from industry, heating, transport, farming, etc.) (Bindoff et al. 2013). However, anthropogenic activities such as mining, the oil industry, waste disposal, grazing, fishing, hunting and logging often have greater local impacts.

The observed effects on the environment include changes in species composition (Kharuk et al. 2006; Magomedova et al. 2006; Shiyatov et al. 2007; Frost et al. 2018), abundance of animals and plants (Kharuk et al. 2007; Shuman et al. 2011; Epstein et al. 2018; Figs. 3, 4), species growth and distribution patterns (Sokolov et al. 2017) and annual biological cycles (Forbes et al. 2016).

Other environmental changes relate to permafrost thaw (Anisimov and Reneva 2006; Pavlov and Malkova 2010; Schaefer et al. 2011; Chadburn et al. 2017) and its impacts on epidemiological situation (Popova 2016; Bogdanov and
Golovatin 2017), changes in hydrology (Streletskiy et al. 2015), biogeochemical cycles (Karelin and Zamolodchikov 2008; Naumov 2009; Golubyatnikov et al. 2013; Zubrzycki et al. 2014) and coastal sea ice retreat (AMAP 2017a).

In addition to the longer-term trends described above, climate change impacts Siberian and global weather systems, increasing the frequency and intensity of extreme weather events. Examples are local scale hurricanes, tornados, extreme dry/wet periods (e.g. Forbes et al. 2016) and increased frequency of tundra and forest fires (BretHarte et al. 2013). Another example is the rapid methane release from below-ground reservoirs that can cause explosions, creating craters in the physical landscape (Kizyakov et al. 2017). This is potentially dangerous if future explosions occur under oil and gas pipelines.

\section{The main global consequences and teleconnections of environmental changes in Siberia}

Human-induced climate change is driven by a global demand for resources and, in combination with anthropogenic climate variability and various feedback mechanisms (Cohen et al. 2012), has resulted in the observed pattern of climate change.

The speed of change observed in Siberian ecosystems is fast (see Tchebakova et al. 2010; Shvidenko and Schepaschenko 2013; Bukvareva et al. 2015) resulting in little time for communities and society to adapt. Increased frequency and magnitude of extreme events, which are difficult to predict, also make it difficult to be prepared without adequate prediction abilities and warning systems. While 


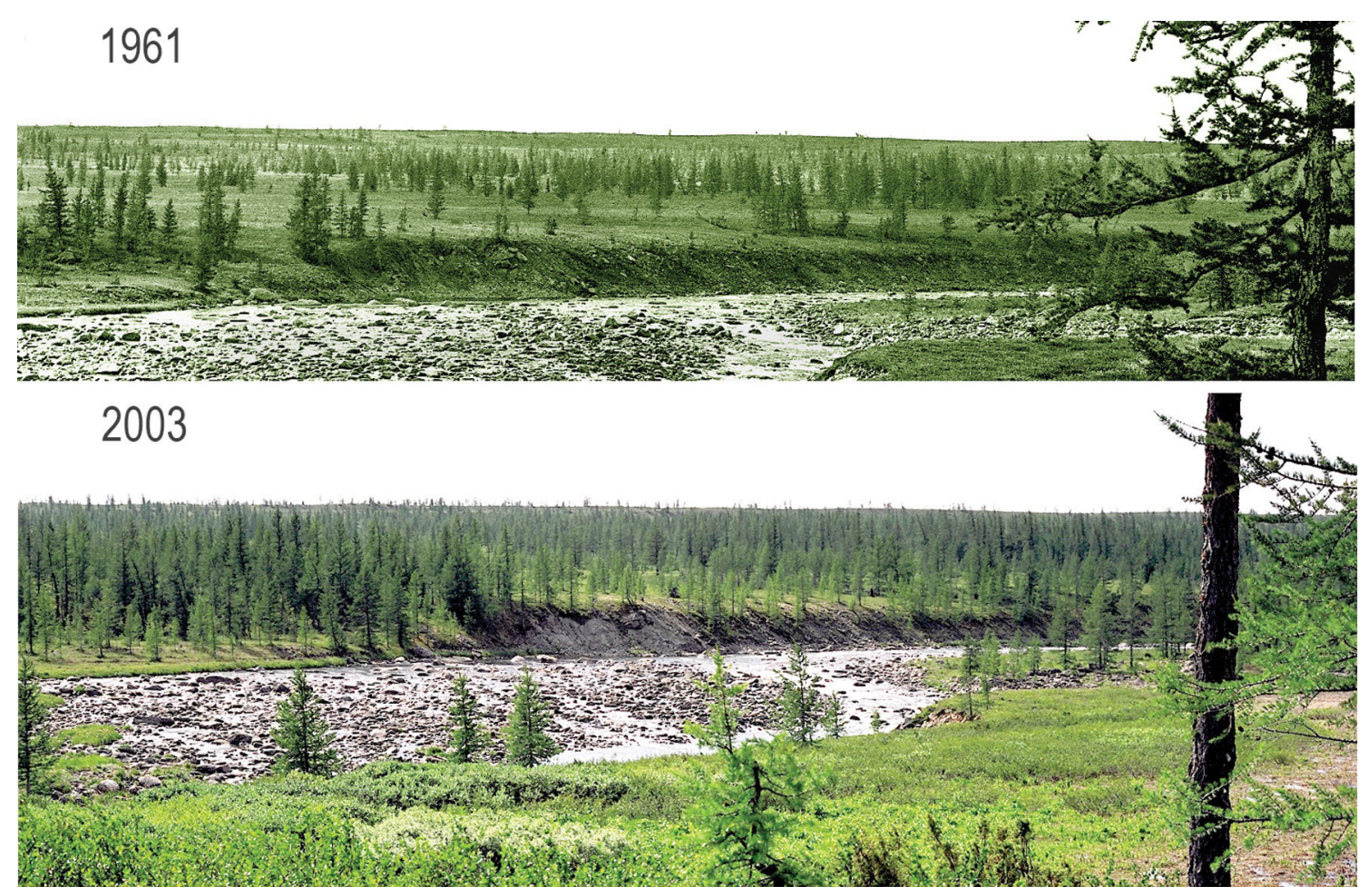

Fig. 3 Thickening of the larch forest on the left banks of the Enga-Yu River, Polar Urals, near Salekhard (Photos: Prof. Stepan G. Shiyatov, IPAE URAN)
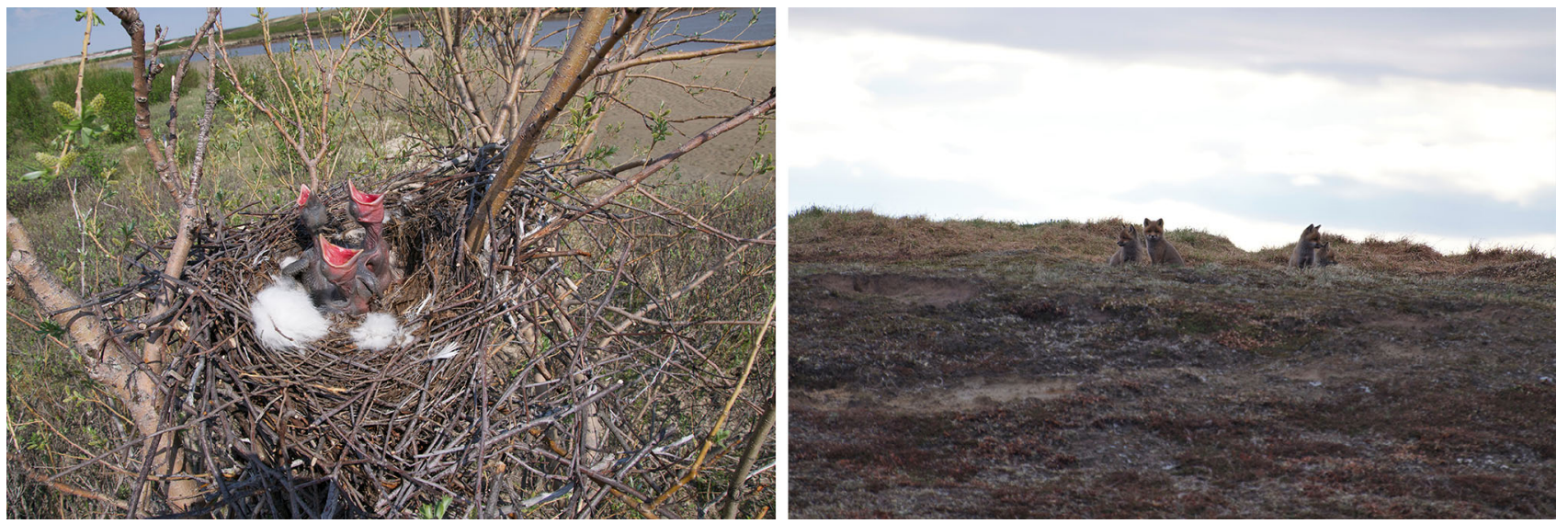

Fig. 4 Observed effects on the environment include changes in species abundance. Here, breeding of crows and red fox at $68^{\circ}$ N. Photos: A. Sokolov (2014)

the impacts of climate change vary across the globe, the majority of the world's population will experience changes in climate and weather systems and thus be affected by a rapidly changing climate and associated extreme weather events. Where populations are not directly affected adversely by climate change, they are likely to be subjected to in-migration from populations suffering dramatic changes such as coastal flooding and desertification.

Processes in Siberia with global consequences include (a) changes in albedo caused by changes in snow cover, cloud cover, vegetation type and aerosols from anthropogenic emissions and natural fires, (b) changes in biogeochemical cycles such as increased emissions of greenhouse gases resulting from changes in temperature and precipitation patterns (Pokrovsky et al. 2015; Serikova et al. 2018), (c) possible changes in the highly, annually variable "Siberian High" [climatological high pressure system: see, e.g. Marshall et al. 2016], which will impact weather across much of Eurasia and (d) increases in extreme weather events outside the Arctic (e.g. Cohen et al. 
2014 among many others) linked to Arctic amplification and to the greater frequency of severe winters in the densely populated Northern Hemisphere mid-latitudes.

\section{Major local societal impacts of environmental change and coping strategies}

Determining and mitigating impacts of environmental change on local societies require preservation of indigenous knowledge (Eira et al. 2018) and increased knowledge of coping strategies (Rakhmanova 2018). An example is the instability of reindeer husbandry livelihoods under changing environmental conditions because decreases in the abundance of lichens and other forage plants such as horsetails reduce reindeer weight and force the herders to move to new areas (Lavrillier and Gabyshev 2017). Although reindeer herding can potentially benefit by modifying herding methods to sociological and climate change impacts (e.g. Tyler et al. 2007), such as land abandonment (Eilertsen 2002), there is a general need for diversification of livelihood strategies because of the instability of traditional livelihoods such as reindeer husbandry and fishing, and the risk of losing some plant species which are used traditionally for food and medical purposes. Strategies also need to be developed to cope with new pests and diseases (affecting both reindeer and people) that are likely to be introduced as a result of climate change, increased exchange of goods and human movement.

In contrast to adverse changes for local societies to cope with, there are, and will be, new opportunities, for example the introduction of new cultivated plant species. Changing climate may allow for the production of more southerly crops and hence offer an opportunity for diversification of livelihoods. However, new coping strategies should not be at the expense of traditional systems.

\section{Communication with local communities}

The researchers acknowledged that local and indigenous peoples (especially those relying on natural resources) have an experienced and inherited knowledge of their environments and ecosystems and of local society. Although some knowledge is being lost (Eira et al. 2018) this type of knowledge is valuable for the research community when developing and designing research and monitoring projects/ programmes, or when analysing and interpreting results.

New technologies are readily adopted in some local communities, but used less in others. Where new communication tools such as Internet are adopted, this offers opportunities for the improved exchange of information between scientists and community members and for informing local communities about extreme events (an example of good cooperation between scientists, local communities and decision-makers).
In a research perspective, cooperation with local communities is important for ethical reasons, e.g. making monitoring activities of scientists more transparent for the communities and making Northern Peoples active participants within studies, rather than passive study foci for the academic community and decision-makers. Research questions and study designs should be discussed and accepted together and traditional knowledge should be part of the research projects (Joint Statement of Ministers, 26 Oct 2018). It is important to directly involve, where possible, local and indigenous peoples in environmental monitoring programmes through a community-based research approach and through citizen science programmes. The information obtained needs to be disseminated further to schools, decision-makers and the general public so that local communities can learn about the required diversification of livelihood strategies and treatment of illnesses, etc.

\section{Communication with decision-makers}

Local communities and scientists possess knowledge of the natural environment and society that can be used by decision-makers in adaptation processes, whether these are caused by climate change or globalization, and decisionmakers can, through funding opportunities, shape research and monitoring programmes to address local, regional, national and global concerns.

In a research perspective, cooperation with decisionmakers is important for making decision-makers aware of changes in climate, ecosystems, environment and society and the impacts of these changes. It is also important to ensure that research and monitoring programmes are relevant for societal challenges perceived by local peoples and decision-makers. Cooperation with decision-makers also provides a platform to lobby for funding of prioritized research and monitoring topics.

\section{Recommendations from scientists to improve the efficiency of working together}

The dialogue reported here among local and indigenous peoples, decision-makers and scientists was partly facilitated by INTERACT (www.eu-interact.org), a network of 86 research stations in 18 countries including all the Arctic nations. The network was often considered (below) to be a vehicle for implementing many of the recommendations. The recommendations from the scientists were as follows:

- There is an obvious need for fundamental science to advise best practice under future environmental conditions. 
Table 1 Case studies highlighting three key issues where scientists, local and indigenous peoples and local decision-makers need to work together to ensure sustainable Northern futures

\begin{tabular}{|c|c|c|c|c|c|}
\hline Case study & Area & Key stakeholders & Key issue & Key processes & Recommendations \\
\hline $\begin{array}{l}\text { 1. Living } \\
\text { resources of } \\
\text { the } \\
\text { Southern } \\
\text { Taiga }\end{array}$ & $\begin{array}{l}\text { River Ob flood } \\
\text { plain, } \\
\text { western } \\
\text { Siberia }\end{array}$ & $\begin{array}{l}\text { - Regional } \\
\text { Administration } \\
\text { - Hunters and } \\
\text { Fishermen } \\
\text { - Universities } \\
\text { - Private farmers } \\
\text { - State collective } \\
\text { farmers }\end{array}$ & $\begin{array}{l}\text { Interaction between fishing } \\
\text { and hunting livelihoods of } \\
\text { local people on one hand, } \\
\text { and conservation } \\
\text { regulations on the other }\end{array}$ & $\begin{array}{l}\text { - Beaver population } \\
\text { growth } \\
\text { - Fishing quotas }\end{array}$ & $\begin{array}{l}\text { Develop a new legislation based } \\
\text { on informed recommendations } \\
\text { from the research community } \\
\text { and land users, e.g. hunters } \\
\text { fishermen and conservationists } \\
\text { Ensure a fair and transparent } \\
\text { decision-making process } \\
\text { through dialogue among stake } \\
\text { holders }\end{array}$ \\
\hline $\begin{array}{l}\text { 2. Pressure on } \\
\text { reindeer } \\
\text { pastures in } \\
\text { the Russian } \\
\text { tundra }\end{array}$ & $\begin{array}{l}\text { Yamalo-Nenets } \\
\text { Autonomous } \\
\text { District, } \\
\text { Siberia }\end{array}$ & $\begin{array}{l}\text {-Reindeer herding } \\
\text { enterprises } \\
\text {-Individual } \\
\text { reindeer herders } \\
\text { and their } \\
\text { families } \\
\text {-Local } \\
\text { Government } \\
\text { - Oil and gas } \\
\text { industry }\end{array}$ & $\begin{array}{l}\text { Interaction between } \\
\text { indigenous peoples } \\
\text { traditional livelihoods and } \\
\text { general development (e.g. } \\
\text { infrastructure) in the area }\end{array}$ & $\begin{array}{l}\text { - Increased numbers } \\
\text { of reindeer } \\
\text { - Reduced and } \\
\text { fragmented pasture } \\
\text { areas }\end{array}$ & $\begin{array}{l}\text { Calculate the current reindeer } \\
\text { capacity of the pastures from a } \\
\text { geobotanical survey } \\
\text { Encourage local and federal } \\
\text { authorities to provide essential } \\
\text { regulation and legislation with } \\
\text { the help of Nenets (and other) } \\
\text { herders to ensure sustainable } \\
\text { reindeer husbandry }\end{array}$ \\
\hline $\begin{array}{l}\text { 3. Reindeer } \\
\text { herding and } \\
\text { tourism in } \\
\text { Scandinavia }\end{array}$ & $\begin{array}{l}\text { Northern } \\
\text { Scandinavia } \\
\text { (sub-Arctic) }\end{array}$ & $\begin{array}{l}\text { - Reindeer herders } \\
\text { - Herding } \\
\text { authorities } \\
\text { - Research } \\
\text { institutions } \\
\text { (Stations and } \\
\text { Universities } \\
\text { including } \\
\text { Tromsø, Umeå) } \\
\text { - Forest industry } \\
\text { - Mining industry } \\
\text { - Hunting and } \\
\text { fishing } \\
\text { associations } \\
\text { - Conservation } \\
\text { authorities } \\
\text { - Tourism } \\
\text { businesses }\end{array}$ & $\begin{array}{l}\text { Interaction between traditional } \\
\text { land use (reindeer } \\
\text { husbandry) and increasing } \\
\text { tourism business }\end{array}$ & $\begin{array}{l}\text { - Reduced and altered } \\
\text { snow season and } \\
\text { poor winter } \\
\text { conditions in the } \\
\text { European Alps } \\
\text { - Increased tourism } \\
\text { activities in the } \\
\text { North } \\
\text { - Decreased } \\
\text { opportunities for } \\
\text { winter pasture for } \\
\text { reindeer and } \\
\text { increased } \\
\text { disturbance to herds }\end{array}$ & $\begin{array}{l}\text { Ensure that tourist operators, local } \\
\text { and indigenous peoples have } \\
\text { good dialogues (use existing } \\
\text { good example between reindeer } \\
\text { herders and the operators of the } \\
\text { Finnmarkløpet as a model for } \\
\text { other tourist activities) to } \\
\text { advise local decision-makers on } \\
\text { actions needed to ensure } \\
\text { sustainable tourism and } \\
\text { reindeer husbandry in the area }\end{array}$ \\
\hline
\end{tabular}

- Coherent messages from scientists to decision-makers are essential and these could be produced by using standardized circumpolar data sets.

- Cooperation between research stations and local people should be improved. INTERACT will contribute by providing a printed book for station managers on appropriate and successful practices for engaging with local people (see 3 examples briefly summarized in Table 1 and in Electronic Supplementary Material S1).

- Protocols should be published so that, for example new research stations, projects and individual local communities can interpret their local data in a pan-Arctic context.
- The INTERACT Station Managers' Forum, where station managers meet, can serve as a place for training and sharing best practices.

- Support and funding is essential for further development of environmental monitoring networks throughout the vast and environmentally diverse Russian Arctic to inform local decision-making. It would be highly beneficial to launch a new network of research and monitoring stations in the Yamal-Nenets Autonomous region of Russia that has the advantage of being linked to the wider Siberian Environmental Change Network, the pan-Arctic INTERACT and numerous other relevant single-discipline networks.

- SecNet stations should also be included within INTERACT to unify the protocols that are used in 
monitoring and research, and the networks should be widely advertised for Russian institutions to join.

- The combined networks can serve as an early warning system for potentially hazardous events building on the one-stop-shop initiative developing within INTERACT.

- Transporting samples taken from the field and sent across national borders for analysis should be made easier by reducing and/or removing the barriers of cross-border import/export.

- Global ethical concepts should be adopted by any new stations from the Yamal-Nenets Autonomous Region, SecNet and INTERACT.

- Achievements of Russian science, and successful interfaces between this science and local and indigenous peoples and decision-makers, are mostly invisible for the international society. The process of integrating these achievements into the global community is not fast, and a greater coordination of information flow should be introduced. This could be done via, for example a Science Forum, where the research opportunities in the Russian Arctic and dialogues among researchers, local peoples and decision-makers could be promoted.

\section{ISSUES PERCEIVED BY LOCAL PEOPLES}

\section{Background to the contribution of information from local communities}

Representatives of different Siberian indigenous peoples living on the territory of the Yamal-Nenets and KhantyMansiysk Autonomous districts, Yakutia, Chukotka, Murmansk and the Arkhangelsk Region were willing to discuss urgent problems. In addition, indigenous peoples from Norway, Finland and Sweden were invited to provide their perspectives and discuss common issues. However, the methodology and format of the science-based workshop sometimes caused them to be perplexed, because they were accustomed to a different way of generating ideas and decision-making. Differences in the tactics of the discussion were also noticeable between English-speaking reindeer herders of Scandinavia and reindeer herders of Siberia, who built a dialogue through an interpreter. Also, the group consisted of local people who have received higher education and are engaged in counselling and assisting representatives of indigenous peoples. This participant structure shows that the model of discussion was initially set in a paradigm that is close to Eurocentric, which sets a dialogue with people from the "nomadic world" within the realities of European standards of consumption, health care, transport systems, communications and life support in general.

\section{Issues relating to health and well-being of local populations}

The participants were immersed in environmental and management discourses to a varying degree, and their statements represented different levels of understanding of the proposed problems. The discussion was, therefore, a result of a combination of scientific and "everyday" logic, manifested from the "inside" of traditional culture. The perceptions of issues related to health and well-being varied between the Scandinavian and Russian reindeer herders in some cases as their national infrastructure and economy lead to different living conditions. However, there were shared concerns on some issues.

Russian reindeer herders, practising reindeer husbandry in the Yamal-Nenets Autonomous District, recognized several key issues related to their well-being and health including the absence of frequent ambulance flights, the importance of maintaining traditional food sources, the depletion of pastures for reindeer (as meat is the basis of their diet), and for local people from settlements where fish is the basis of the diet, the problem of declining fish stocks in rivers and lakes. The final key issue identified was a declining immune system as this is weakened when the centuries-old "diet" and eating habits change under the influence of changing anthropogenic and natural factors.

Scandinavian reindeer herders, practising reindeer husbandry in northern Norway, Sweden and Finland, commented that the main cause of the imbalance in the lives of Northern indigenous peoples compared to the well-being of people from cities is that indigenous knowledge is not included in the scope of informational resources for the process of decision-making by governing structures and is, therefore, not part of the public debate ("Knowledge of indigenous people is not included in the structure of discussion by the decision makers"). This observation emphasizes the need for indigenous peoples to have a greater dialogue with decision-makers and a greater role in decision-making processes that affect their well-being and also the need to protect indigenous knowledge as a "living" resource (Eira et al. 2018).

Both the Scandinavian (Saami) and Russian (Nenets, Khanty and Yakuts) participants shared the views that mobility with migrating reindeer herds and nomadic lifestyle are key factors for well-being and both physical and mental health. It was perceived that the abrupt transition to a settled way of life in villages and towns is leading to psychological instability (L. Rakhmanova, pers. obs. based on interviews), reduced immunity and more frequent cases of diseases of various kinds, for example cardiovascular 
diseases and diabetes (Rautio et al. 2014). The transformation from nomadic to a sedentary way of life may also lead to psychosomatic disorders. A sedentary lifestyle can lead to obesity, particularly in men, but also in women which affects the reproductive health of the population. Also, the change of the rhythm of life and the resulting free time, atypical for the nomadic way of life, leads to alcohol abuse among some Northern Peoples (Lobanov et al. 2017; Martinchik et al. 2017). Equally important to the well-being of the local population is the safety and quality of food and water and the control of its handling, transport and storage, i.e. food security.

Perhaps the most significant integrator of the issues documented above is the life expectancy of the indigenous peoples of the Arctic taiga and tundra zones. Life expectancy and mortality rates are the indicators that are most easily captured and recorded by community members themselves, and therefore, they begin to "sound the alarm" even before the demographic statistics recognize any crisis situation (Rautio et al. 2014). According to the indigenous peoples of the North, especially in the territory of the Russian Federation, life expectancy is decreasing because of the declining quality of their lives, provoked by an attempt to apply to the Arctic realms the criteria developed for social policy in milder climatic conditions. According to interviews with local residents (Kargasok district of the Tomsk Region, Nizhnevartovsk and Surgut Districts of the Khanty-Mansiysk Autonomous District, Nadym, and Purovsky Districts of the Yamal-Nenets Autonomous District), there is an increased anxiety about the life expectancy of the populations. However, local perceptions of living conditions, health and longevity differ from the existing statistics that show an increase. This contradiction can be explained by two factors. First, health and life expectancy are linked by local people directly to environmental conditions. Despite the increase in the quality of medical care in these regions, trends from the position of local residents show deterioration in health and a decrease in the number of long-lived people. Secondly, during the interviews, we found out that the term "life expectancy" is interpreted by ordinary people in a slightly different way compared to the interpretation used by municipal administrations and scientists: they believe that long-lived people are the ones who can perform various functions: economic, social and family, until their last days. Therefore, although life expectancy has actually increased in the regions, the period of active life of citizens, especially men, has decreased. Added to the concerns over life expectancy is a change in demography because in the taiga, populations are decreasing due to abandonment of agricultural land and villages and a movement to towns and cities.

\section{Perceptions of issues related to environmental and climate change}

Ongoing climate change in Siberia and northern Scandinavia results in abnormally hot summer seasons and floods that increasingly affect coastal communities. These changes, in turn, have led to a successful invasion of rare species of insects that have been absent before. The growing populations of horseflies and mosquitoes have a significant impact on tundra and taiga reindeer husbandry. In addition, newly arrived birds and insects may transmit new viruses and diseases from southern regions. These may be particularly dangerous to inhabitants of the Northern regions who do not have appropriate immunity (Popova 2016; Bonebrake et al. 2018; Waits et al. 2018).

Ongoing climate change also affects Arctic biodiversity through species increase, decrease, immigration or emigration. Resulting dramatic changes in the migration patterns of wild animals, birds and fish change the fishing, hunting and conservation practices of local populations (see Case Study 1 in Table 1 and Electronic Supplementary Material S1). Biodiversity is also affected by the increasing human presence in the Arctic that results in niche loss, habitat loss and habitat fragmentation for many species (e.g. Taran 2018).

The observed changes in snow conditions in the Arctic and, concurrently, in the southern regions, have many impacts in the North. Decreasing snow cover in the South leads to an increasing demand for Arctic tours. This, in turn, is triggering a "tourist invasion". Snowmobile and road trips in sparsely populated areas of the Scandinavian Peninsula cross the paths of herders' migrations and invade the historically established areas of intensive traditional land use (see Case Study 3 in Table 1 and Electronic Supplementary Material S1). In addition, there is a threat of fragmentation of nomadic cultural space caused by the sale and long-term lease of the land on which reindeer pastures are located. These changes are supported by new land legislation regarding land rights in disputed territories, for example the number of concessions given to the extractive industry sector in disputed territories has increased, especially in Sweden and Finland.

One global result of climate change was articulated by a Saami reindeer herder who said that "a positive effect of climate change is that the world community has finally focused on the needs of indigenous people" and, in fact, on the Arctic in general.

\section{Expectations of local peoples on scientists and interactions between them}

History has shown that communities are able to adapt to past and present changes in local environments (Fig. 5) and 

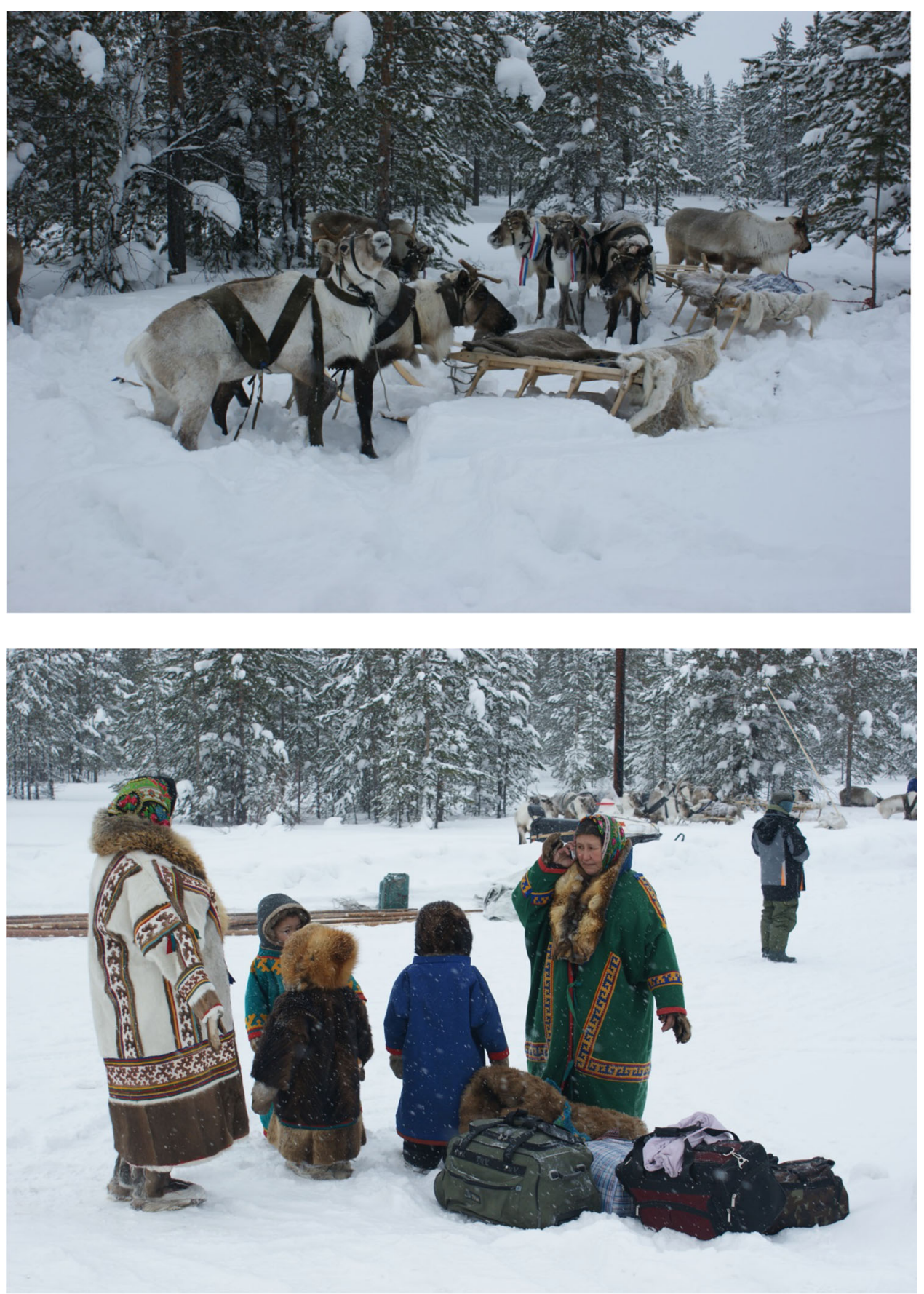

Fig. 5 People of the North are affected by climate change and globalization. For example, Khanty People keep many of their traditions such as use of reindeer but are part of modern society using mobile phones, snow scooters, etc. (Photos: S. Kirpotin)

ecosystems, as well as to the influx of external societal development processes and technology, although the changes are not always desirable for all the community members [e.g. western diet (Harvald and Hansen 2000)]. In some cases, new technology opportunities are quickly adopted by many (e.g. mobile phones, GPS, snow scooters, radio frequency identification for reindeer tagging [NIBIO 2016 Meld St. 2016-2017], but in other cases local and traditional knowledge systems are no longer adequate or relevant for facilitating adaptation to current changes (both environmental and globalization). In this latter case, input from scientists is essential. However, field studies by scientists from different disciplines can be considered by local residents in two basic ways: as an invasion into their culture and everyday life and/or as an activity that brings them new information, opens up new perspectives and helps 
them to adapt to the changing environmental and socioeconomic conditions of life in the Arctic.

\section{Recommendations from local and indigenous peoples to improve the efficiency of working together}

- A "translation" of scientific language is required to make scientific knowledge clear and understandable to the indigenous population of the Arctic ("let's make science language clear and understandable"). It is possible that one of the steps to solve this problem of "translation" could be the appearance of a new generation of scientists from the communities of indigenous peoples. The most effective and most demanded types of specialization in education for young reindeer herders and their families are medicine and veterinary science.

- Researchers often depend on accessing lands occupied by local peoples and they often receive help and information. However, far too often, researchers leave behind disturbance and research artefacts but not knowledge. Feedback from scientists from their work should be a pre-requisite for their access to the field. Information to local communities from long-term field research would be particularly important, and scientists should provide the most relevant data to the inhabitants and in an understandable way. For example, information on endangered and rare animal species and other natural resources that should be protected to maintain a balance in the ecosystem for the benefit of future generations could be very useful. Other helpful data that were identified were weather reports, long-term weather/climate projections, forecasts of the dynamics of water levels in rivers and access to economic forecasts that are important to maintain livelihood stability.

- It is also recommended that, in parallel, researchers should request advice from experts among the indigenous population ("feedback from the locals to scientists"). This means that local people should no longer be the "object" of research, but rather a participant in the research process. The principles of research ethics suggest that researchers should be "prepared" for interacting with local people before going into the field in order to avoid their own culture shock, and so as not to cause trauma due to this intervention to the local community. A deeper form of partnership with the local residents should involve the joint formulation of research questions and hypotheses to make research more relevant to local peoples. Such practices are well developed in the Canadian and USA Arctic (Hitomi and
Loring 2018) and are presented in "Principles for the Conduct of Research in the Arctic", https://www.nsf. gov/geo/opp/arctic/conduct.jsp).

- Local peoples did not focus on mechanisms of improving dialogue with decision-makers but rather focused on various forms of action and support they required from decision-makers at regional and federal levels of government. There was an indication of some misstrust between the groups because local peoples perceived that some aspects of current dialogue between local populations and administrations were failing. An example offered was conscious or involuntary misinformation to the population about ongoing natural disasters, emergencies, economic crises and changes, and changes in social policy.

- Decision-makers should take an intermediary position of communication between scientists and local people. Decision-makers can also develop an organizational infrastructure that enables the process of mutual tripartite consultation of the stakeholders (local population, scientists and managers) and a greater role for local peoples in decision-making processes.

- Decision-makers in Siberia should strive to over-turn the inequality in the distribution of benefits, subsidies and other resources between "sovhozes" (state farms owning reindeer herds left from the Soviet times) and individual reindeer herders who are often deprived of their rights and opportunities which are instead granted to "brigades" (groups of herders taking care of stateowned reindeer for a fixed salary).

- Government and municipal authorities should also strive to over-turn the perceived inequality in the support for Nenets who dominate the ethnic groups of Yamal (which is a multi-ethnic region). Other ethnic groups such as Khanty and Selkups apparently receive less support.

- Environmental consciousness in the Arctic zone requires legislative regulation of the quotas and methods for hunting, reindeer husbandry and fishing. An important issue is to find a balanced way of developing reindeer husbandry while maintaining its uniqueness and balancing legislature with local flexibility.

- Decision-makers are encouraged to shift the focus on energy sources from existing fossil fuels to alternative energy sources. From the reindeer herders' perspective, this would slow down the destruction of the habitat for reindeer and other Arctic animals and plants. From the researchers' perspective, it would reduce the level of global greenhouse gases.

- To ensure that Northern indigenous peoples' way of life can be protected and preserved, current regulations need to be revised as regulation for some species of 
animals will no longer be appropriate in a changing climate.

\section{ISSUES PERCEIVED BY DECISION-MAKERS}

\section{Major challenges for sustainable development}

A working definition of sustainable development "Development which respects local environment and local people with long term viability prioritized over short-term gain" was used to identify several issues. A current aim of the government of the Russian Federation is to increase the population of Northern regions (Eremenko 2014; Fauzer 2014; Gagiev 2016; Kiseleva and Gokova 2016) but firstly, there should be an assessment of how this policy would affect the environment. Furthermore, cost implications of settlement should be considered. When starting new industrial projects, especially in the high Arctic, an important decision should be made between encouraging settlement by shift workers or settlers with families as sustaining the life of each individual is extremely expensive (Efremov 2014). This expense originates from providing a degree of "comfort" appropriate to inhabitants in the world of modern city-dwellers. However, there is a dilemma: what degree of comfort should be provided for indigenous nomads? On one hand, when planning the modernization of local peoples' lives, they should not be forced to change their lifestyle whereas they should have access to the advances of modern medicine and education. Providing "modern facilities" has increased infant survival and life expectancy in the tundra-living human population. An increasing population leads to new issues that need to be solved such as the danger of reindeer pasture overgrazing in the Yamal-Nenets Autonomous District (See Case Study 2, Table 1 and Electronic Supplementary Material S1).

\section{Opportunities and challenges for communicating with local and indigenous peoples}

Local and indigenous peoples perceive current issues from a very long-term perspective as their ancestors have been living in the tundra for centuries. Now they see how companies come to drill for oil and gas on their native lands. Even if they are not harmed by this intervention (Forbes 2013), local people understand that companies are making large profits and local people want to have their fair share. As a rule, companies are not against a dialogue, but the local and indigenous peoples should know from the beginning exactly what they want.
In such dialogues, there is an inequality of negotiating positions, as both sides see the other as a potential opponent and do not understand the way of thinking of their "opponent". Furthermore, each side has a very different level of empowerment from which they can influence the situation, the local peoples having a much weaker power base than the decision-makers. This fundamental division is amplified by divisions within the local communities. Representatives are chosen from the local communities and sent to negotiations where they become known by Government and are elevated to a privileged sector of their former local community. This leads to separation and perhaps alienation from the rest of their original community. After this stage has been reached, it is questionable if the Northern People's representatives faithfully represent their local communities. This situation has an analogue among the decision-makers when representatives of local government interact at the Federal level.

The decision-makers identified that "Talent loss" hinders dialogue with local communities. Talented young people from local backgrounds that leave to get higher education in large cities often fail to return to their homeland so there is a lack of educated people within local communities to interact with decision-makers.

A complex question decision-makers have to be ready to answer in the dialogue with local and indigenous peoples is what happens with the Arctic territories after oil and gas reserves have been exhausted. Which types of development should be used then to sustain the current quality of life resulting from the high profits from the previous exploitation of carbon deposits?

\section{Opportunities and challenges for communicating with scientists}

The Government has the difficult choice of assigning funding priorities to applied science that could solve important, urgent problems or fundamental research, hoping to have exciting results in the future. Specialists coming from the 'big land' outside are not aware of the local specific conditions, so they are harder to communicate with. According to federal law, environmental impact assessments should be carried out for all construction work or mining activity. However, the quality of such assessments is not always satisfactory, and the companies rarely, if ever, share the results with the scientific community who could comment on the adequacy of the assessment and the weakness of field work or analysis.

There is a lack of locally trained scientists in the Russian Arctic. For example, there is no University in the YamalNenets Autonomous District. Local science exists in some of the Arctic regions of Siberia but it is hard for the institutions concerned to develop in the same way as large 
federal scientific institutions. Also, international research programmes tend not to collaborate with small, local institutions, failing to share results and not involving local specialists in the field work.

There is a need to develop a coherent message from scientists as to what scientific monitoring priorities are. A good example of when the global scientific community set out to measure one clearly defined parameter that leads to a clear result, and is therefore well-funded, is the CALM (Circumpolar Active-Layer Monitoring) programme (Brown et al. 2000).

\section{How should decision-makers respond to current and likely future hazardous events?}

Fundamental science is needed to advise best practice under future environmental conditions as hazardous events are becoming more frequent. Examples are strong blizzards late in the season, and extremely hot summers that facilitate the spread of spores of Anthrax (see Case Study 2 in Table 1 and Electronic Supplementary Material S1). We still cannot predict these events in advance. More knowledge-based decision-making is needed to identify and respond to such events. Hence, support and funding for monitoring networks are needed in the Russian Arctic to inform decision-makers on likely future hazardous events, preferably in cooperation with the INTERACT "rapid response to potential environmental hazards" activity.

Building regulations need to be updated to account for the heterogeneity in local conditions and future change, as current ones are based on 1980s knowledge. Permafrost thawing is becoming a real problem for pipelines and buildings (e.g. "new" ( $<10$ years old) tall buildings are already facing challenges).

\section{Recommendations from decision-makers to improve the efficiency of working together}

- To achieve improved communication, all three groups should use a language that is understandable for everyone, e.g. by avoiding jargon.

- Training opportunities should be provided for scientists, local and indigenous peoples and policy-makers to learn to speak each other's languages. Scientists should learn to understand legal frameworks and how the government systems work in order to write policy briefs; decision-makers should learn the basic principles of research and the way the local and indigenous peoples' lives are organized; local and indigenous peoples should learn in which way science could help them and also their legal rights.

- Each group should be as specific as possible regarding what they need from the other groups.

- Funding should be found to support the training of local and indigenous peoples to work as rangers on their land and this would also be beneficial for scientists, e.g. by looking after scientific equipment for a small salary.

- The trust between local and indigenous peoples and other groups, particularly policy-makers, researchers and the media, should be increased keeping in mind that trust can only be established by long-term contact.

- At a wider geographic scale, one of the obstacles hindering international collaboration is the difficulty for foreigners to access the Arctic part of Russia as it is considered "a border zone". Requests for a visit should be sent two months in advance and it is not always possible to plan ahead. It would help if decision-makers could make this procedure easier for visiting scientists.

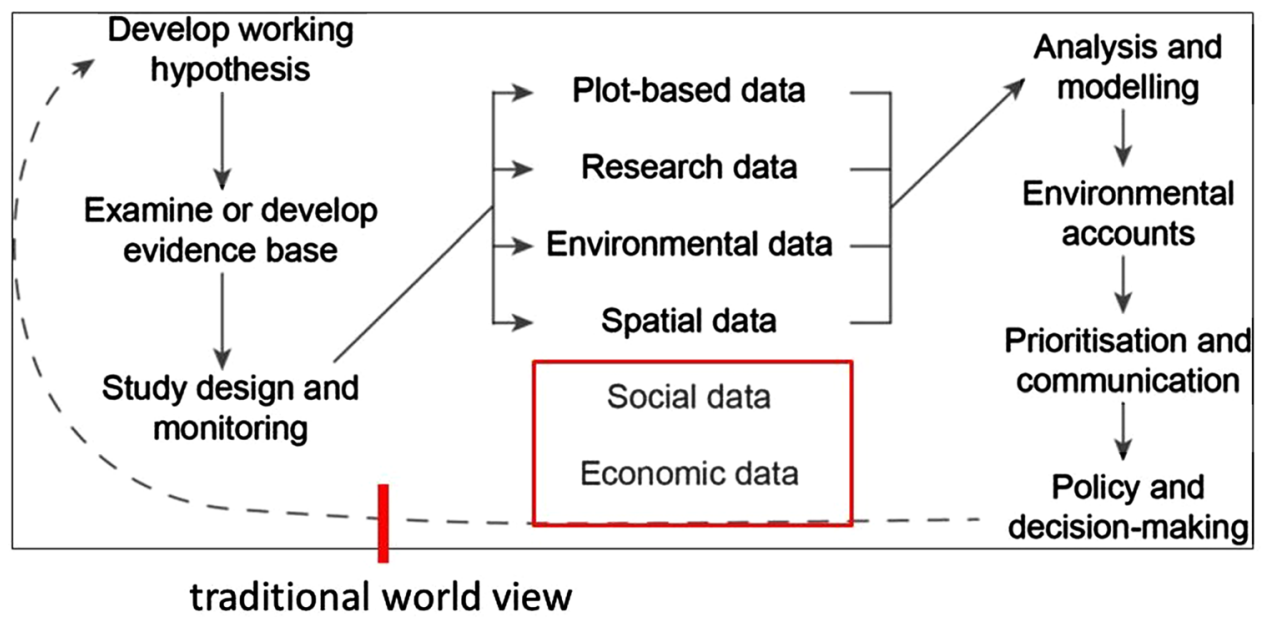

Fig. 6 The critical barrier in a conceptual model highlighting key linkages between monitoring and environmental reporting (Lindenmayer et al. 2015) 


\section{Winter Weather and Climate Extremes: how can researchers, authorities and local peoples work together to record, predict and adapt?}

Based on a very successful workshop between decision makers, researchers and indigenous and local peoples in the Yamal-Nenets Autonomous District, Siberia and beyond, the participants resolve to improve dialogue among these groups by:

- $\quad$ Preparing guidelines of good practice for the three groups to work together. For example, developing guidelines for research stations to improve interactions with local communities.

- Recognising and using multiple "ways of knowing". For example, using the power of combining science observations with the knowledge and observing capacity of indigenous and local peoples to initiate research into unique, and potentially hazardous, environmental events and other impacts of climate change.

- Consulting widely when constructing research agendas to ensure the research is relevant, encompasses all sectors, knowledge types, disciplines, and peoples and is sustainable to its conclusion.

- $\quad$ Ensuring that the three groups work together to review the effectiveness of existing legislature and possible requirements for new laws relating to conflict in land use arising from environmental change. For example, developing regulations to prevent uncontrolled business activities in the Arctic due to climate change.

- Improving the impact of research by making science agendas and findings available in a variety of formats and languages and informing decision makers; from research planning, through implementation, to dissemination of results.

- Ensuring communication at multiple geographical levels and seeking comparability and synergies among local, regional, pan-Arctic and global scales to maximise information flow to decision makers at all levels. For example, the Science and Innovation Department of the Government of the Yamal-Nenets Autonomous District will join relevant existing networks selected from listings compiled by the INTERACT pan-Arctic network of research infrastructures.

- Improving communication at all levels of society with particular emphasis on capacitybuilding through education; ensuring that developing researchers, decision makers and local and indigenous peoples interact and develop a better mutual understanding from the outset.

Fig. 7 Siberian Environmental Change Network 2017 Workshop Resolution 
- An established scheme, e.g. by Lindenmayer et al. (2015) should be used to improve dialogue among the various actors (Fig. 6).

\section{THREE CASE STUDIES OF COLLABORATION BETWEEN RESEARCHERS, LOCAL AND INDIGENOUS PEOPLES AND DECISION- MAKERS}

Three case studies of collaboration between the groups have been carried out and are summarized in Table 1. Full details are found in the Electronic Supplementary Material S1.

\section{OVERALL CONCLUSIONS}

Ongoing climate change and societal development in Siberia and other northern areas affect local communities and livelihoods as well as general developments in society. The ongoing and projected rapid changes in natural systems (climate and ecosystems), extreme events, new pests and deceases, and new opportunities (sea transport routes, crops, tourism, etc.) all put pressure on society to adaptfrom individuals, households and communities to regional, national and global institutions.

A communication platform for information exchange and cooperation is required for the dialogue between local and indigenous peoples, decision-makers and scientists. Such a platform can be used to develop potential environmental hazard detection systems, discuss research and monitoring priorities and discuss adaptation needs that benefit all groups.

Bringing indigenous peoples, decision-makers and researchers together has started this process at a small-scale and has led to a new state-of-the-art understanding based on different perceptions of similar phenomena and a dialogue has been established among the three groups resulting in an agreed resolution (Fig. 7). It is important to highlight that the representatives of the different groups have completely different perceptions of the events happening in everyday life so hardly ever understand each other in official dialogue. The format of the workshop described here forced the different groups to listen to the other side, giving participants insights into the other groups' ways of thinking and thus helped to overcome perceived obstacles to effective communication between the groups. Furthermore, the study is state-of-the-art in making perceptions from discussions among Russian decision-makers, indigenous peoples and researchers globally accessible.
Since the meeting, all three groups have worked together successfully to achieve some of the aims and recommendations presented here: indigenous peoples are working with scientists and decision-makers to establish new research stations and environmental monitoring sites, and a citizen science programme is developing centred on Nadym that involves indigenous peoples, scientists, health workers and oil and gas employees. Hopefully, these small steps will multiply quickly.

\section{IMPORTANT NOTE}

During the preparation of this manuscript, a few participants withdrew because they believed (a) "Stimulating (and sponsoring) local people to live in XIX century and use their traditional way of life in these days of technologies is simply not appropriate". (b) "In case of on-going climate warming, there will be only BENEFITS for Russian (mostly Siberian) economy". (c) "Most of on-going ecosystem changes are NATURAL as they did occur in the past". (d) "THERE WILL BE NO REAL increases in concentration and fluxes of carbon and related elements in case of on-going climate warming and permafrost boundary shift northward and the increase of the thickness of the 'active' unfrozen layer due to permafrost thaw". (e) Some of the statements regarding indigenous peoples and reindeer grazing were seen as controversial. These statements emphasize the need for both greater interactions between researchers and local peoples and researchers with different interpretations of current climate change and its impacts. The meeting that led to this study and opposing views will hopefully stimulate a continuation of a critically important dialogue both within and among the three groups.

Acknowledgements We are grateful to all participants who attended the meeting, the Government of the Yamal-Nenets Autonomous District for hosting and co-funding the meeting, The Science and Innovation Network of the British Embassy, Moscow for co-funding, The Siberian Environmental Change Network of Tomsk State University and INTERACT for co-funding and support. TVC is grateful for the support from the Tomsk State University competitiveness improvement programme, and SK is grateful for financial support of the Russian Foundation for Basic Research in the framework of Scientific Project No. 18-05-60264. Finally, we thank the indigenous peoples from Siberia and Scandinavia who left their reindeer herding, hunting and fishing work to share their knowledge and perceptions.

Open Access This article is distributed under the terms of the Creative Commons Attribution 4.0 International License (http:// creativecommons.org/licenses/by/4.0/), which permits unrestricted use, distribution, and reproduction in any medium, provided you give appropriate credit to the original author(s) and the source, provide a link to the Creative Commons license, and indicate if changes were made. 


\section{REFERENCES}

AMAP. 2017a. Snow, water, ice and permafrost in the arctic (SWIPA) 2017. Arctic Monitoring and Assessment Programme (AMAP), Oslo, Norway. xiv +269 pp.

AMAP. 2017b. Adaptation actions for a changing arctic: Perspectives from the Bering-Chukchi-Beaufort region. Arctic Monitoring and Assessment Programme (AMAP), Oslo, Norway. xiv + $255 \mathrm{pp}$.

Anisimov, O., and R. Orttung. 2018. Climate change in Northern Russia through the prism of public perception. Ambio 48: 661-671. https://doi.org/10.1007/s13280-018-1096-x.

Anisimov, O., and S. Reneva. 2006. Permafrost and changing climate: the Russian perspective. Ambio 35: 169-175. https://doi.org/10. 1579/0044-7447.

Bindoff, N.L., P.A. Stott, K.M. Achuta Rao, M.R. Allen, N. Gillett, D. Gutzler, K. Hansingo, G. Hegerl, et al. 2013. Detection and attribution of climate change: From global to regional. In Climate change 2013: The physical science basis. Contribution of working group I to the fifth assessment report of the intergovernmental panel on climate change [Stocker, T.F., D. Qin, G.-K. Plattner, M. Tignor, S.K. Allen, J. Boschung, A. Nauels, Y. Xia] 1217-1308. https://doi.org/10.1017/ cbo9781107415324.028.

Bogdanov, V.D., and M.G. Golovatin. 2017. Anthrax in Yamal: An ecological view on traditional reindeer husbandry. Russian Journal of Ecology 48: 95-100. https://doi.org/10.1134/ S1067413617020059.

Bonebrake, T.C.C.J., J.D. Brown, J.L. Bell, A. Blanchard, C.Champion Chauvenet, I.-Ching Chen, T.D. Clark, et al. 2018. Managing consequences of climate-driven species redistribution requires integration of ecology, conservation and social science. Biological Reviews 93: 284-305.

Bret-Harte, M.S., M.C. Mack, G.R. Shaver, D.C. Huebner, M. Johnston, C.A. Mojica, C. Pizano, and J.A. Reiskind. 2013. The response of Arctic vegetation and soils following an unusually severe tundra fire. Philosophical Transactions of the Royal Society B: Biological Sciences 368: 20120490-20120490. https://doi.org/10.1098/rstb.2012.0490.

Brown, J., K.M. Hinkel, and F.E. Nelson. 2000. The circumpolar activer layer montitoring (CALM) program: Research designs and initial results. Polar Geography 24: 165-258.

Bukvareva, E.N., K. Grunewald, S.N. Bobylev, D.G. Zamolodchikov, A.V. Zimenko, and O. Bastian. 2015. The current state of knowledge of ecosystems and ecosystem services in Russia: A status report. Ambio 44: 491-507. https://doi.org/10.1007/ s13280-015-0674-4.

Chadburn, S.E., E.J. Burke, P.M. Cox, P. Friedlingstein, G. Hugelius, and S. Westermann. 2017. An observation-based constraint on permafrost loss as a function of global warming. Nature Climate Change 7: 340-344. https://doi.org/10.1038/nclimate3262.

Cohen, J., J.A. Screen, J.C. Furtado, M. Barlow, D. Whittleston, D. Coumou, J. Francis, K. Dethloff, et al. 2014. Recent Arctic amplification and extreme mid-latitude weather. Nature Geoscience 7: 627-637. https://doi.org/10.1038/ngeo2234.

Cohen, J.L., J.C. Furtado, M.A. Barlow, V.A. Alexeev, and J.E. Cherry. 2012. Arctic warming, increasing snow cover and widespread boreal winter cooling. Environmental Research Letters 7: 011004. https://doi.org/10.1088/1748-9326/7/1/ 014007.

Efremov, I.A. 2014. Age features of migration processes in the Far North of Russia (in Russian). Demoscope Weekly 581-582.

Eilertsen, S.M. 2002. Utilization of abondoned coastal meadow in northern Norway by reindeer. Thesis, Dept Arctic Biol and Inst Med Biol, Uni Tromsoe, $25 \mathrm{pp}+4$ papers.
Eira, I.M.G., A. Oskal, I. Hanssen-Bauer, and S.D. Mathiesen. 2018. Snow cover and the loss of traditional indigenous knowledge. Nature Climate Change 8: 928-931. https://doi.org/10.1038/ s41558-018-0319-2.

Epstein, H., U. Bhatt, M. Raynolds, D. Walker, J. Pinzon, C.J. Tucker, B.C. Forbes, T. Horstkotte, et al. 2018. Tundra greenness. Bulletin of the American Meteorological Society 99: 165-169.

Eremenko, G. 2014. Influence of demographic and migration flow on labor market in Sakha Republic (Yakutia) (in Russian). Modern Research of Social Problems 34.

Fauzer, V.V. 2014. Demographic potential of the Russia's northern regions as a factor and condition of economic development of the Arctic (in Russian). Economy of Region 2014: 69-81.

Forbes, B.C. 2013. Cultural resilience of social-ecological systems in the Nenets and Yamal-Nenets Autonomous Okrugs, Russia: A focus on reindeer nomads of the tundra. Ecology and Society. https://doi.org/10.5751/ES-05791-180436.

Forbes, B.C., F. Stammler, T. Kumpula, N. Meschtyb, A. Pajunen, and E. Kaarlejärvi. 2009. High resilience in the Yamal-Nenets social-ecological system, West Siberian Arctic, Russia. Proceedings of the National Academy of Sciences 106: 22041-22048. https://doi.org/10.1073/pnas.0908286106.

Forbes, B.C., T. Kumpula, N. Meschtyb, R. Laptander, M. MaciasFauria, P. Zetterberg, M. Verdonen, A. Skarin, et al. 2016. Sea ice, rain-on-snow and tundra reindeer nomadism in Arctic Russia. Biology Letters 12: 20160466. https://doi.org/10.1098/ rsbl.2016.0466.

Francis, J.A., and S.J. Vavrus. 2012. Evidence linking Arctic amplification to extreme weather. Geophysical Research Letters. https://doi.org/10.1029/2012GL051000.

Frost, G.V., H.E. Epstein, D.A. Walker, G. Matyshak, and K. Ermokhina. 2018. Seasonal and long-term changes to activelayer temperatures after tall shrubland expansion and succession in arctic tundra. Ecosystems 21: 507-520. https://doi.org/10. 1007/s10021-017-0165-5.

Gagiev, N. 2016. Demographic features of the development of the northern territories of Russia (in Russian). Regional Economics: Theory and Practice 191-200.

Golubyatnikov, L.L., I.I. Mokhov, and A.V. Eliseev. 2013. Nitrogen cycle in the earth climatic system and its modeling. Izvestiya, Atmospheric and Oceanic Physics 49: 229-243. https://doi.org/ 10.1134/S0001433813030079.

Groisman, P., H. Shugart, D. Kicklighter, G. Henebry, N. Tchebakova, S. Maksyutov, E. Monier, G. Gutman, et al. 2017. Northern Eurasia Future Initiative (NEFI): Facing the challenges and pathways of global change in the twenty-first century. Progress in Earth and Planetary Science. https://doi.org/10. 1186/s40645-017-0154-5.

Harvald, B., and J.P.H. Hansen. 2000. Arctic medical science. In The arctic: Environment, people, policy, ed. M. Nutall and T.V. Callaghan, 315-337. Amsterdam: Hrwood Academic Publishers.

Hitomi, M.K., and P.A. Loring. 2018. Hidden participants and unheard voices? A systematic review of gender, age, and other influences on local and traditional knowledge research in the North. Edited by Nicole L. Klenk. FACETS 3. Canadian Science Publishing 65: 830-848. https://doi.org/10.1139/facets-20180010.

Horowitz, C.A. 2016. Paris agreement. International Legal Materials 55: 740-755. https://doi.org/10.1017/s0020782900004253.

Karelin, D., and D. Zamolodchikov. 2008. Carbon exchange in cryogenic ecosystems. Moscow: Nauka. (in Russian).

Kharuk, V.I., K.J. Ranson, S.T. Im, and M.M. Naurzbaev. 2006. Forest-tundra larch forests and climatic trends. Russian Journal of Ecology 37: 291-298. https://doi.org/10.1134/ S1067413606050018. 
Kharuk, V.I., K.J. Ranson, and E.V. Fedotova. 2007. Spatial pattern of Siberian silkmoth outbreak and taiga mortality. Scandinavian Journal of Forest Research 22: 531-536. https://doi.org/10. 1080/02827580701763656.

Kiseleva, A.M., and O.V. Gokova. 2016. Demographic safety of northern regions: Problems of depopulation and migration (in Russain). Herald of Omsk University Series "Economics."

Kizyakov, A., M. Zimin, A. Sonyushkin, Y. Dvornikov, A. Khomutov, and M. Leibman. 2017. Comparison of gas emission crater geomorphodynamics on Yamal and Gydan Peninsulas (Russia), based on repeat very-high-resolution stereopairs. Remote Sensing of Arctic Tundra 9: 1023

Kumpula, T., B.C. Forbes, F. Stammler, and N. Meschtyb. 2012. Dynamics of a coupled system: Multi-resolution remote sensing in assessing social-ecological responses during 25 years of gas field development in Arctic Russia. Remote Sensing 4: 1046-1068. https://doi.org/10.3390/rs40401046.

Lavrillier, A., and S. Gabyshev. 2017. An Arctic Indigenous knowledge system of landscape, climate, and human interactions, 460. Kulturstiftung Siberien: Evenki Reindeer Herders and Hunters.

Lindenmayer, D.B., E.L. Burns, P. Tennant, C.R. Dickman, P.T. Green, D.A. Keith, D.J. Metcalfe, J. Russell-Smith, et al. 2015. Contemplating the future: Acting now on long-term monitoring to answer 2050's questions. Austral Ecology 40: 213-224.

Lobanov, A.A., A.I. Popov, and T. Popova. 2017. Prevention of excessive consumption of alcohol in YaNAO. Unpublished report (in Russian).

Magomedova, M.A., K.M. Morozova, S.N. Ektova, O.V. Rebristaya, I.V. Chernyadieva, A.D. Potiemkin, and M.S. Kniazev. 2006. Yamal Peninsula: Vegetation cover. Tumen: Citypress. 360 p. (in Russian)

Marshall, G.J., R.M. Vignols, and W.G. Rees. 2016. Climate change in the Kola Peninsula, Arctic Russia, during the last 50 years from meteorological observations. Journal of Climate 29: 6823-6840. https://doi.org/10.1175/JCLI-D-16-0179.1.

Martinchik, A.N., K.V. Kudryavtsev, A.K. Baturin, and A. Lobanov. 2017. Alcohol consumption among the adult population of the arctic zone and the population of other climatic zones. Scientific Herald of Yamalo-Nenets Autonomous Okrug 2: 39-43.

Naumov, A. 2009. Soil respiration: Components, ecological functions and geographical regularirties. Novosibirsk: SO RAN. (in Russian).

Orttung, R.W., and C. Reisser. 2014. Urban sustainability in Russia's arctic: Lessons from a recent conference and areas for further investigations. Polar Geography 37: 193-214. https://doi.org/10. 1080/1088937X.2014.919362.

Overland, J., J. Walsh, and V. Kattsov. 2017. Trends and feedbacks. In Snow, water, ice and permafrost in the arctic (SWIPA) 2017, 9-24. Arctic Monitoring and Assessment Programme (AMAP), Oslo, Norway.

Pavlov, A., and G. Malkova. 2010. Dynamic of permafrost zone of Russia under changing climate conditions (in Russian). Izv. RAS, Geography 5: 44-51.

Pokrovsky, O.S., R.M. Manasypov, S. Loiko, L.S. Shirokova, I.A. Krickov, B.G. Pokrovsky, L.G. Kolesnichenko, S.G. Kopysov, et al. 2015. Permafrost coverage, watershed area and season control of dissolved carbon and major elements in western Siberian rivers. Biogeosciences 12: 6301-6320. https://doi.org/ 10.5194/bg-12-6301-2015.

Popova, A. 2016. Outbreak of anthrax in the Yamalo-Nenets autonomous district in 2016, epidemiological peculiarities. Problems of Particularly Dangerous Infections 4: 42-46.

Rakhmanova, L. 2018. Trial—adaptation—rooting: Understanding and embodiment of the concepts in the Arctic and Siberia. In
Paths of Russia. 1917-2017: One hundred years of changes, 227-244. Moscow, St. Petersburg: Nestor-History.

Rautio A, B. Poppel, and K. Young. 2014. Human health and wellBeing. In Arctic human development report II-regional processes and global linkages, eds. J.N. Larsen and Fondahl G. Tema Nord. ISSN 0908-6692, 567 pp.

Schaefer, K., T. Zhang, L. Bruhwiler, and A.P. Barrett. 2011. Amount and timing of permafrost carbon release in response to climate warming. Chemical and Physical Meteorology 63: 165-180. https://doi.org/10.1111/j.1600-0889.2010.00527.x.

Serikova, S., O.S. Pokrovsky, P. Ala-Aho, V. Kazantsev, S.N. Kirpotin, S.G. Kopysov, I.V. Krickov, H. Laudon, et al. 2018. High riverine $\mathrm{CO}_{2}$ emissions at the permafrost boundary of Western Siberia. Nature Geoscience 11: 825-829. https://doi. org/10.1038/s41561-018-0218-1.

Shiyatov, S.G., M.M. Terent, V.V. Fomin, and N.E. Zimmermann. 2007. Altitudinal and horizontal shifts of the upper boundaries of open and closed forests in the polar urals in the 20th century. Russian Journal of Ecology 38: 223-227. https://doi.org/10. 1134/s1067413607040017.

Shuman, J.K., H.H. Shugart, and T.L. O'Halloran. 2011. Sensitivity of Siberian larch forests to climate change. Global Change Biology 17: 2370-2384. https://doi.org/10.1111/j.1365-2486. 2011.02417.x.

Shvidenko, A.Z., and D.G. Schepaschenko. 2013. Climate change and wildfires in Russia. Contemporary Problems of Ecology 6: 683-692. https://doi.org/10.1134/S199542551307010X.

Sokolov, A., I. Fufachev, V. Sokolov, N. Sokolova, M. Golovatin, and A. Dixon. 2017. Gyrfalcons in a man-made landscape of the Yamal Peninsula (the Yamal-Nenets autonomous district). Fauna of the Urals and Siberia 2: 180-185.

Streletskiy, D., O. Anisimov, and A. Vasiliev. 2015. Permafrost degradation. In Snow and ice-related hazards, risks and disasters, 303-344. Amsterdam: Academic Press. https://doi.org/10. 1016/b978-0-12-394849-6.00010-x.

Taran, G.S. 2018. Floristic records on the Ob River floodplain, Tomsk region. Systematic Notes 117: 35-39. https://doi.org/10.17223/ 20764103.117.4. (in Russia).

Tchebakova, N.M., G.E. Rehfeldt, and E.I. Parfenova. 2010. From vegetation zones to climatypes: Effects of climate warming on Siberian ecosystems, 427-446. Springer, Dordrecht. https://doi. org/10.1007/978-1-4020-9693-8_22.

Tyler, N.J.C., J.M. Turi, M.A. Sundset, K. Strøm-Bull, M.N. Sara, E. Reinert, N. Oskal, C. Nellemann, et al. 2007. Saami reindeer pastoralism under climate change: Applying a generalized framework for vulnerability studies to a sub-arctic socialecological system. Global Environmental Change 17: 191-206.

Waits, A., A. Emelyanova, A. Oksanen, K. Abass, and A. Rautio. 2018. Human infectious diseases and the changing climate in the Arctic. Environment International 121: 703-713. https://doi.org/ 10.1016/J.ENVINT.2018.09.042.

Zubrzycki, S., L. Kutzbach, and E.M. Pfeiffer. 2014. Permafrostaffected soils and their carbon pools with a focus on the Russian Arctic. Solid Earth 5: 595-609. https://doi.org/10.5194/se-5-5952014.

Publisher's Note Springer Nature remains neutral with regard to jurisdictional claims in published maps and institutional affiliations.

\section{AUTHOR BIOGRAPHIES}

Terry V. Callaghan $(\bowtie)$ is a Professor of Arctic Biology at the University of Sheffield, UK, Professor of Botany at the Tomsk State University, Russia, Member of Royal Swedish Academy of Sciences, Sweden. His research interests include Arctic Ecology and climate change and Science Diplomacy. 
Address: University of Sheffield, Alfred Denny Building, Western Bank, Sheffield S10 2TN, UK.

Address: Tomsk State University, 36 Lenina Pr, Tomsk, Russia 634050.

e-mail: terry_callaghan@btinternet.com

Olga Kulikova is a doctoral candidate at the University of Konstanz in Germany, a research assistant in the Institute of the Biological Problems of the North, Magadan and research scientist at the Tomsk State University. Her research interests include Arctic ecosystems, raptor ecology and migration ecology of birds.

Address: Tomsk State University, 36 Lenina Pr, Tomsk, Russia 634050.

Address: University of Konstanz, Constance, Germany.

Address: Institute of the Biological Problems of the North, Russian Academy of Sciences, Portovaya Street 18, Magadan, Russia 685000. e-mail: gaerlach@gmail.com

Lidia Rakhmanova is a senior research scientist at the National Research University Higher School of Economics in St. Petersburg and at the Tomsk State University. Her research interests include social anthropology, ethics of socio-anthropological research, climate change perception, adaptation processes, natural resources management and lifeworlds of isolated Siberian villages.

Address: 28 Promyshlennaya str, Saint-Petersburg, Russia 190121.

Address: Tomsk State University, 36 Lenina Pr, Tomsk, Russia 634050.

e-mail: muza-spb@yandex.ru

Elmer Topp-Jørgensen is a special consultant at the Department of Bioscience of the Aarhus University, Denmark. His research interests include Arctic Environment conservation.

Address: Department of Bioscience, Arctic Research Center, Aarhus University, Frederiksborgvej 399, Building 7418, I2.41, 4000 Roskilde, Denmark.

e-mail: jetj@bios.au.dk

Niklas Labba is the Academic Director at the Centre for Sámi Studies (Sesam) at the Arctic University of Norway. His research interests include impacts of changing climate on reindeer husbandry. Address: Centre for Sámi Studies, University of Troms $\varnothing$, Postboks 6050, Langnes, 9037 Tromsö, Norway.

e-mail: niklas.labba@uit.no

Lars-Anders Kuhmanen is the Chair of Gabna Sámi Village in northernmost Scandinavia. He works with reindeer husbandry. Address: Gabna Sámi Village, Scandinavia, Norway.

e-mail: lakuhmunen@hotmail.com

Sergey Kirpotin is a Professor at the Tomsk State University. His research interests include landscape ecology, Arctic studies, geocryology, remote sensing, plant ecology and biogeochemistry.

Address: Tomsk State University, 36 Lenina Pr, Tomsk, Russia 634050.

e-mail: kirp@mail.tsu.ru

Olga Shaduyko is a Director of the Excellence Support Unit of Tomsk State University, Russia. Her research interests include international collaboration, Siberian research.

Address: Tomsk State University, 36 Lenina Pr, Tomsk, Russia 634050.

e-mail: dolcezzamia@mail.ru

Henry Burgess is the Head of the Natural Environment Research Council Arctic Office, UK. His professional interests include international scientific cooperation across all aspects of Arctic research.
Address: British Antarctic Survey, UK Natural Environment Research Council Arctic Office, High Cross, Madingley Road, Cambridge CB3 OET, UK.

e-mail: henrge@bas.ac.uk

Arja Rautio is a Professor, Director of Thule Institute, University of Oulu, Finland, and University of the Arctic Vice-president Research. Her research interests include Arctic Health and well-being.

Address: Thule Institute, University of Oulu and University of the Arctic, P.O. Box 7300 90014, Oulu, Finland.

e-mail: arja.rautio@oulu.fi

Ruth S. Hindshaw is a former APECS (Association of Polar Early Career Scientists) president and was a post-doctoral researcher at the University of Cambridge. Her research focuses on the water chemistry of rivers draining glaciated and permafrost-dominated landscapes.

Address: Norconsult AS, Kjørboveien 22, 1338 Sandvika, Norway. e-mail: ruth.hindshaw@gmail.com

Leonid L. Golubyatnikov is a senior research scientist at the A.M. Obukhov Institute of Atmospheric Physics, Moscow. His research interests include climate change impact on the vegetation, remote sensing, methane fluxes for terrestrial ecosystems, models of carbon and nitrogen cycles.

Address: A.M. Obukhov Institute of Atmospheric Physics, 3 Pyzhevsky Lane, Moscow, Russia 119017.

e-mail: golub@ifaran.ru

Gareth J. Marshall is a Senior Climatologist of the British Antarctic Survey, UK Natural Environment Research Council. His research interests include climate variability and climate changes in Antarctica.

Address: British Antarctic Survey, UK Natural Environment Research Council Arctic Office, High Cross, Madingley Road, Cambridge CB3 OET, UK.

e-mail: gjma@bas.ac.uk

Andrey Lobanov is a Doctor of Medicine, deputy head of the Arctic Research Centre of the Yamal-Nenets autonomous district, Nadym. His research interests include Arctic health and well-being of local and indigenous people, climate change and its societal impact adaptations.

Address: Arctic Research Centre of the Yamal-Nenets Autonomous District, Line 8, Nadym, Russia 629730.

e-mail: alobanov89@gmail.com

Andrey Soromotin is a Professor at the Tyumen State University and Director of the Research Institute of Ecology and Natural Resources Management, Tyumen. His research interests include geoecology, landscape ecology, bioremediation of the sand areas on the Arctic and Earth's remote sensing.

Address: Research Institute of Ecology and Natural Resources Management, Tumen State University, 6 Volodarskogo St, Tyumen, Russia 625003.

e-mail: a.v.soromotin@utmn.ru

Alexander Sokolov is the Deputy Head at the Arctic Research Station of Institute of Plant and Animal Ecology of UB of RAS and senior researcher at the Arctic Research Center of Yamal-Nenets Autonomous District. His research interests include population ecology, biodiversity, food web and Arctic studies.

Address: Arctic Research Station, Institute of Plant \& Animal Ecology Ural Branch, Russian Academy of Sciences, 21, Str. Zelenaya Gorka, Labytnangi, Russia 629400. 
Address: Arctic Research Center of Yamal-Nenets Autonomous District, 73, Str. Respublika, Salekhard, Russia 629008.

e-mail: sokhol@yandex.ru

Natalia Sokolova is a researcher at the Arctic Research Station of Institute of Plant and Animal Ecology of UB of RAS and at the Arctic Research Center of Yamal-Nenets Autonomous District. Her research interests include population ecology, biodiversity, food web and Arctic studies.

Address: Arctic Research Station, Institute of Plant \& Animal Ecology Ural Branch, Russian Academy of Sciences, 21, Str. Zelenaya Gorka, Labytnangi, Russia 629400.

Address: Arctic Research Center of Yamal-Nenets Autonomous District, 73, Str. Respublika, Salekhard, Russia 629008.

e-mail: nasokolova@yandex.ru
Praskovia Filant is a representative of the non-profit Reindeer herders Association of the Yamal-Nenets autonomous district. Her research interests include traditional knowledge and legal assistance for indigenous peoples.

Address: Reindeer Herders Association of the Yamal-Nenets Autonomous District, of. 35, 41 Sverdlov Str, Salekhard, Russia 629007. e-mail: filant76@mail.ru

Margareta Johansson is a research coordinator at Lund University in Sweden. Her research interests include climate change in the Arctic and its impacts focusing on permafrost.

Address: Department of Physical Geography and Ecosystem Science, Lund University, Solvegatan 12, 22362 Lund, Sweden.

e-mail: margareta.johansson@nateko.lu.se 